\title{
Microbial Dynamics as Influenced by Bio-organics and Mineral Fertilizer in Alluvium Soil of Varanasi, India
}

\author{
R. Verma ${ }^{1 *}$, B.R. Maurya ${ }^{2}$, V.S. Meena ${ }^{3}$, M.L. Dotaniya ${ }^{4}$ and P. Deewan ${ }^{1}$ \\ ${ }^{1}$ SKN College of Agriculture, Sri Karan Narendra Agricultural University, Jobner-303 329, India \\ ${ }^{2}$ Institute of Agricultural Sciences, BHU, Varanasi-221005, India \\ ${ }^{3}$ ICAR-Vivekananda Parvatiya Krishi Anusandhan Sansathan, Almora-263601, India \\ ${ }^{4}$ ICAR-Indian Institute of Soil Science, Bhopal-462 038, India \\ *Corresponding author
}

\section{A B S T R A C T}

\begin{tabular}{|l|}
\hline Key w or d s \\
Microbial population, \\
Enzymetic activity, \\
Pseudomonas \\
fluorescens, Humic \\
acid and mineral \\
fertilizer.
\end{tabular}

\section{Introduction}

Modern agriculture production requires efficient, sustainable and environmentally sound management practices as the judicious application of bio-organic with mineral fertilizers to increase fertilizer use efficiency is need of an hour. The Use of effective bioorganics like biofertilizers, plant growth promoting microorganisms and humic substances for improved crop growth and soil health is one of the viable alternatives. The goal for the majority of organic substances research has been to identify the best growing conditions possible for best crop establishment and improves soil physical (Allison, 1962) and chemical and biological properties are important for plant health, soil environment (Yassen and Khalid, 2009). Organic matter is one of the most important components when evaluating the general fertility of a soil (Ding et al., 2002). In agricultural soils, organic matter consists mainly of plant biopolymer residues, 
materials derived from them via the decomposition processes, microbial tissues and humic substances (Chefetz et al., 2000).

The microbial activity can be used as index of soil fertility and microbial functional diversity (Nannipieri et al., 2002 and Meena et al., 2014). Soil micro flora is biological indicator of soil quality because of the relationship to decomposition and nutrient cycling, ease and rapid response to changes in soil management (Dilly et al., 2003). Microbial population as well as enzymatic activity and other biological properties (viz. SMBC, $\mathrm{CO}_{2}$ evolution, $\mathrm{C}$ : $\mathrm{N}$ ratio) and phosphatase, indicate that incorporation of bio-organic material had contributed significantly to soil organic carbon, total nitrogen lead to greater microbial biomass and subsequently to greater enzyme synthesis and accumulation in the soil matrix (Dinesh et al., 2000). Soil microbial biomass has been used as an index of soil fertility which depends on nutrient fluxes (Hassink, 1991). Enzymatic activities have been proposed as a tool to monitor changes in soil ecology resulting from the interactions between inoculants and indigenous microbial populations of soil (Doyle and Stotzky, 1993). Soil enzyme assay is an indirect indication on the activities of microbes which is directly correlated with soil microbial dynamics. Soil enzyme activity varies with soil type and is influenced by the texture and the content of organic matter of the soils (Tarafdar and Jungk, 1987). The objective of this study was to evaluate the microbial dynamics as influenced by bio-organics and mineral fertilizer in alluvium soil.

\section{Material and Methods}

The studies pertaining to the effect of Pseudomonas fluorescens and humic acid with mineral fertilizer on cabbage was conducted at Vegetable Research Farm,
Institute of Agricultural Sciences, Banaras Hindu University, Varanasi $\left(25^{\circ} 18^{\prime} \mathrm{N}\right.$ latitude, $83^{\circ} 03^{\prime} \mathrm{E}$ longitude and $128.93 \mathrm{~m}$ MSL). The experiment was laid out in Randomized Block Design with three replications. The experiment consist of ten treatment combinations viz., [( $\left.\mathrm{T}_{1}\right) 100 \% \mathrm{RDF}$ (control), $\left(\mathrm{T}_{2}\right) 50 \% \mathrm{RDF}+$ Pseudomonas fluorescens, $\left(\mathrm{T}_{3}\right) 75 \% \mathrm{RDF}+$ Pseudomonas fluorescens, $\left(\mathrm{T}_{4}\right) 100 \% \mathrm{RDF}+$ Pseudomonas fluorescens, $\left(\mathrm{T}_{5}\right) 50 \% \mathrm{RDF}+$ Humic acid, $\left(\mathrm{T}_{6}\right) 75 \% \mathrm{RDF}+$ Humic acid, $\left(\mathrm{T}_{7}\right) 100 \% \mathrm{RDF}$ + Humic acid, $\left(\mathrm{T}_{8}\right) 50 \% \mathrm{RDF}+$ Pseudomonas fluorescens + Humic acid, $\left(\mathrm{T}_{9}\right) 75 \% \mathrm{RDF}+$ Pseudomonas fluorescens + Humic acid $\left(\mathrm{T}_{10}\right)$ $100 \%$ RDF + Pseudomonas fluorescens + Humic acid. Cabbage seedlings were raised in seedbeds of $5 \times 4 \mathrm{~m}$ size using seeds of cabbage var. Golden Acre F1 hybrid produced by Sakata Seed Corporation, Japan. Recommended dose of fertilizers were $120 \mathrm{~N}$ : $60 \mathrm{P}_{2} \mathrm{O}_{5}: 60 \quad \mathrm{~K}_{2} \mathrm{O} \mathrm{kg} / \mathrm{ha}$. Nursery raised transplanting, fertilization and crop cultivation practices according to Verma et al., (2014).

\section{Soil sampling}

Initial soil samples were collected prior to the start of the experiment from surface soil (0-15 $\mathrm{cm}$ depth) and analyzed for physicochemical properties (Table 1). At harvest of cabbage, the rhizospheric soil collected from surrounding of cabbage plant roots from each plot at harvesting of crop and brought to laboratory. For microbial analysis soil samples were kept at 4 o $\mathrm{C}$ in plastic bags for a few days to stabilize the microbiological activity disturbed during soil sampling and handling, and then analysed. Total bacteria, fungi and actinomycetes were estimated by following the standard procedure of Rolf and Bakken (1987) and dehydrogenase and urease (Tabatabai, 1994) and alkaline phosphatase activity measured by Tabatabai and Bremner, (1986). 


\section{Statistical analysis}

Statistical analysis of the data was done by using analysis of variance (ANOVA), assessed by Panse and Sukhatme (1985), with a probability, the treatment mean were compared at $\mathrm{P}<0.05$ by using the statistical computer programme MSTAT, version 5.

\section{Results and Discussion}

Microbial population: Microbial population was influenced by the application of mineral fertilizer levels and $P$. fluorescens with humic acid in both year of experimentation have been presented in table 2. Microbial population as bacteria, fungi and actinomycetes increased with increasing dose of mineral fertilizers with the combination of Pseudomonas and humic acid. The Pooled data showed that bacterial population varied 26 to $40 \mathrm{cfu} X 10^{5} \mathrm{~g}^{-1}$ soil. Maximum $40 \mathrm{cfu}$ X $10^{5} \mathrm{~g}^{-1}$ soil bacterial population was recorded with $100 \% \mathrm{RDF}+P$. fluorescens + humic acid showed its superiority over rest of the treatments. This treatment gave 57.3, 13.1 and $14.7 \%$ higher bacterial population than control, $100 \% \mathrm{RDF}+$ P. fluorescens and 100 $\%$ RDF + humic acid, respectively. Humic acid caused $1.42 \%$ higher bacterial population as compared to $P$. fluorescens inoculation. Minimum $26 \mathrm{cfu} \times 10^{5} \mathrm{~g}^{-1}$ soil bacterial population was recorded with $100 \%$ RDF which was statistically at par to $50 \%$ $\mathrm{RDF}+$ P. fluorescens and $50 \% \mathrm{RDF}+$ humic acid. With the application of mineral fertilizer, $P$. fluorescens and humic acid as nutrient source, bio stimulator and organic substrate, there was significant increase in total bacterial population which might be due to the increased microbial functional diversity of soil (Meena et al., 2014). Manna et al. (1996) reported an increase in microbial growth, enzymatic activities and availability of nutrients with the addition of carbon substrate and bio-inoculants are positively related to bacterial population of soil. Similar results have been agreed with by Eissa $e t$ al., (2007) and Awasthi et al., (2011).

It is also apparent from the pooled data that mineral fertilizer levels with $P$. fluorescens and humic acid had significant increased of actinomycetes population of soil at harvest. The treatment $100 \% \mathrm{RDF}+P$. fluorescens + humic acid gave maximum $29 \mathrm{cfu} \times 10^{-4} \mathrm{~g}^{-1}$ soil actinomycetes population in soil which showed its significant superiority over rest of the treatments. This treatment caused 32.0, 13.9 and 15.65 greater actinomycetes population than $100 \% \mathrm{RDF}, 50 \%+P$. fluorescens and 50\% RDF + humic acid, respectively. Minimum $22 \mathrm{cfu} X 10^{4} \mathrm{~g}^{-1}$ soil actinomycetes population in soil was recorded with $100 \%$ RDF which was statistically at par with 50\% RDF $+P$. fluorescens and 50\% RDF + humic acid. Each of $P$. fluorescens and humic acid with fertilizer combination showing highly significant increased actinomycetes population over the remaining treatments at harvest of cabbage might be due to addition of carbon substrate and bio sources (Manna et al., 1996). Similar results augmented by Ismail et al., (2007) and Timothy et al., (2010).

The pooled data showed that fungal population was varied 17 to $25 \mathrm{cfu} \times 10^{4} \mathrm{~g}^{-1}$ soil. Maximum $25 \mathrm{cfu} \mathrm{X} 10^{4} \mathrm{~g}^{-1}$ soil fungal population was recorded with $100 \% \mathrm{RDF}+$ $P$. fluorescens + humic acid which showed its significant superiority over to rest of treatments. This treatment gave 47.0, 15.1 and $16.8 \%$ greater fungal population than control, $100 \% \mathrm{RDF}+P$. fluorescens and $100 \%$ RDF + humic acid, respectively. Humic acid caused $1.47 \%$ greater fungal population as compared to $P$. fluorescens inoculation. Minimum $17 \mathrm{cfu} \mathrm{X} 10^{4} \mathrm{~g}^{-1}$ soil fungal population was recorded with $100 \%$ RDF which was statistically at par with 50 
$\% \mathrm{RDF}+P$. fluorescens and $50 \% \mathrm{RDF}+$ humic acid. This might be due to acidophilic nature of fungi. There was increase in fungal population from initial to post harvest soil. Variation of fungal population was also influenced by age of the plant (Kumari, 1961). The availability of nutrients and organic carbon is positively related with fungal population in soil Naseby and Lynch, (1998) and Awasthi et al., (2011). Patil and Varade (1998) reported that populations of bacteria, actinomycetes and fungi significantly differed with rate of fertilizer treatments and proliferate under $\mathrm{N}, \mathrm{P}, \mathrm{K}$ and bioinoculants with organic substances. Fertilizer and Bio-organics had a profound influence on the microbial population of the soil which in turn, affected the rate of assimilation of nutrients (John and Abraham, 1995).

\section{Soil enzymatic activities}

Enzymatic activities have been proposed as a tool to monitor changes in soil ecology resulting from the interactions between inoculants and indigenous microbial populations of soil (Doyle and Stotzky, 1993). In the present investigation, urease, dehydrogenase, and phosphatase activities significantly increased at harvest of cabbage rhizospheric soil due to application of levels of mineral fertilizer with Pseudomonas fluorescens and humic acid. The pooled data showed that the maximum dehydrogenase activity $\left(142 \mu \mathrm{g}\right.$ TPF g ${ }^{-1}$ soil day $\left.{ }^{-1}\right)$ was the treatment received with $100 \%$ RDF + Pseudomonas fluorescens + humic acid which showed its significant superiority over rest of the treatments. This treatment caused 55.5, 3.5 and $4.8 \%$ greater dehydrogenase activity than control, $100 \%$ $\mathrm{RDF}+$ Pseudomonas fluorescens and $100 \%$ RDF + humic acid, respectively. Humic acid gave $1.2 \%$ greater dehydrogenase activity of soil as compared to $P$. fluorescens inoculation. Minimum dehydrogenase activity $\left(91 \mu \mathrm{g}\right.$ TPF $\mathrm{g}^{-1}$ soil day $^{-1}$ ) was observed with $100 \%$ RDF which was statistically at par with 50\% RDF $+P$. fluorescens and 50\% RDF + humic acid. This indicates that effect of Pseudomonas fluorescens and humic acid was similar in increasing dehydrogenase activity. Similar findings were also reported by Selamuthu and Govindaswamy (2003) in sugarcane, they observed increase in dehydrogenase activity with application of humic acid which might be attributed to organic carbon content of humic substance applied. It may be due to higher organic matter content and relatively higher organic carbon (Wlodarczyk et al., 2002). Similar finding also were observed by Naseby and Lynch (1998); Eissa et al., (2007); Timothy et al., (2010).

Urease is an important enzyme to responsible for the hydrolysis of urea fertilizer applied to the soil into $\mathrm{NH}_{3}$ and $\mathrm{CO}_{2}$ with the concomitant rise in soil $\mathrm{pH}$ (Byrnes and Amberger, 1989. The pooled data showed that urease activity varied from 225 to $310 \mu \mathrm{g}$ urea hydrolyzed $\mathrm{g}^{-1}$ soil $\mathrm{h}^{-1}$. Maximum $310 \mu \mathrm{g}$ urea hydrolyzed $\mathrm{g}^{-1}$ soil $\mathrm{h}^{-1}$ urease activity was recorded with $100 \%$ RDF $+P$. fluorescens + humic acid which showed its significant superiority over to rest of the treatments. This treatment gave 37.7, 0.72 and $5.6 \%$ greater urease activity than control, $100 \% \mathrm{RDF}+P$. fluorescens and $100 \% \mathrm{RDF}+$ humic acid, respectively. Humic acid caused $4.9 \%$ greater urease activity of soil as compared to $P$. fluorescens inoculation. Minimum $225 \mu \mathrm{g}$ urea hydrolyzed $\mathrm{g}^{-1}$ soil $\mathrm{h}^{-1}$ urease activity was recorded with $100 \% \mathrm{RDF}$ which was statistically at par with $50 \%$ RDF + P. fluorescens and 50\% RDF + humic acid. It could be attributed due to their higher $\mathrm{N}$ content and faster decomposition and release of $\mathrm{NH}_{4}-\mathrm{N}$. Crop growth stages also influenced the urease activity. Under field conditions, urease activity was highest at head formation 
stage in compared to initial crop growth stage could be related to lower microbial biomass. Enzymatic activities of soils are usually correlated with their organic carbon and available $\mathrm{N}$ contents (Taylor et al., 2002).

Higher levels of organic carbon stimulate microbial activity, and therefore enzyme synthesis. Similar results were also reported by Naseby and Lynch, 1998; Ismail et al., 2007; Fliessbach et al., 2009. Organic phosphorus in soil can comprise 30 to $70 \%$ of the total phosphorus content.

Hydrolysis of these organic phosphorus compounds is essential for phosphorus nutrition of plants and microorganisms, which is carried out by the enzyme alkaline phosphatase (Tabatabai, 1994). Pooled data showed that alkaline phosphatase activity varied from 35.4 to $63.7 \mu \mathrm{g}$ PNP g ${ }^{-1}$ Soil h$^{-1}$ at harvest.

Maximum 63.7 $\mu \mathrm{g}$ PNP g ${ }^{-1}$ soil $\mathrm{h}^{-1}$ alkaline phosphatase activity was recorded with $100 \% \mathrm{RDF}+P$. fluorescens + humic acid which showed its significant superiority over to rest of the treatments. This treatment gave $80.3,15.2$ and $19.0 \%$ greater alkaline phosphatase activity than control, 100\% $\mathrm{RDF}+$ P. fluorescens and 100\% RDF + humic acid, respectively. Application of humic acid increased $3.2 \%$ alkaline phosphatase activity from $P$. fluorescens inoculation. Minimum 35.4 $\mu \mathrm{g}$ PNP $\mathrm{g}^{-1}$ soil $\mathrm{h}^{-1}$ alkaline phosphatase activity was recorded with $100 \%$ RDF which was statistically at par with $50 \% \mathrm{RDF}+P$. fluorescens and 50\% RDF + humic acid.

Table.1 Initial physico-chemical soil properties of experimental field

\begin{tabular}{|c|c|c|c|c|}
\hline \multirow{2}{*}{ Parameters } & \multicolumn{3}{|c|}{ Value } & \multirow{2}{*}{ Method } \\
\hline & 2009 & 2010 & Mean & \\
\hline \multicolumn{5}{|l|}{ Physico-chemical Properties } \\
\hline $\mathrm{pH}$ (1:2.5 soil water ratio) & 7.81 & 7.69 & 7.75 & \multirow[t]{2}{*}{ Jackson (1973) } \\
\hline $\mathrm{EC}\left(\mathrm{dSm}^{-1}\right.$ at $\left.25^{0} \mathrm{C}\right)$ & 0.221 & 0.217 & 0.219 & \\
\hline Organic carbon $(\%)$ & 0.37 & 0.39 & 0.38 & Walkley and Black \\
\hline Available Nitrogen $\left(\mathrm{kg} \mathrm{ha}^{-1}\right)$ & 192 & 196 & 194 & Subbaiah and Asija \\
\hline Available Phosphors $\left(\mathrm{kg} \mathrm{ha}^{-1}\right)$ & 21.95 & 22.62 & 22.29 & Olsen’s (1954) \\
\hline Available Potassium $\left(\mathrm{kg} \mathrm{ha}^{-1}\right)$ & 213 & 217 & 215 & Jackson (1973) \\
\hline \multicolumn{5}{|l|}{ Biological Properties } \\
\hline Bacteria $\left(\mathrm{CFU} \times 10^{5} \mathrm{~g}^{-1}\right.$ soil $)$ & 21.30 & 22.80 & 22.05 & \multirow{3}{*}{ Rolf and Bakken (1987) } \\
\hline Actinomycetes $\left(\mathrm{CFU} \times 10^{4} \mathrm{~g}^{-1}\right)$ & 7.6 & 7.9 & 7.75 & \\
\hline Fungi $\left(\mathrm{CFU} \times 10^{4} \mathrm{~g}^{-1}\right.$ soil $)$ & 14.10 & 14.70 & 14.40 & \\
\hline Dehydrogenase activity ( $\mu \mathrm{g} \mathrm{TPF}^{-1}$ soil day $^{-1}$ ) & 45.67 & 48.02 & 46.85 & Tabatabai (1994) \\
\hline Alkaline Phosphates activity ( $\mu \mathrm{g}$ PNP $\mathrm{g}^{-1}$ soil $^{-1}$ ) & 19.49 & 20.74 & 20.12 & Tabatabai and Bremner1986) \\
\hline Urease activity $\left(\mu \mathrm{g} \mathrm{UH} \mathrm{g}^{-1}\right.$ soil $\left.^{-1}\right)$ & 123.4 & 126.39 & 124.89 & Douglas Bremner (1971) \\
\hline
\end{tabular}


Table.2 Effect of $P$. fluorescens, humic acid and level of mineral fertilizers on microbial population of cabbage rhizospheric soil at harvest

\begin{tabular}{|c|c|c|c|c|c|c|c|c|c|}
\hline \multirow[t]{2}{*}{ Treatments } & \multicolumn{3}{|c|}{$\begin{array}{c}\text { Bacteria (cfu } \times 10^{5} \mathrm{~g}^{-1} \\
\text { soil) }\end{array}$} & \multicolumn{3}{|c|}{$\begin{array}{c}\text { Actinomycetes }\left(\mathrm{cfu} \times 10^{4} \mathrm{~g}\right. \\
\text { soil })\end{array}$} & \multicolumn{3}{|c|}{$\begin{array}{c}\text { Fungi (cfu } \times 10^{4} \mathrm{~g}^{-1} \\
\text { soil) }\end{array}$} \\
\hline & 2009 & 2010 & Pooled & 2009 & 2010 & Pooled & 2009 & 2010 & Pooled \\
\hline $\mathrm{T}_{1}-100 \% \mathrm{RDF}$ & 26 & 25 & 26 & 21 & 23 & 22 & 15 & 18 & 17 \\
\hline $\begin{array}{l}\mathrm{T}_{2}-50 \% \mathrm{RDF}+P \text {. } \\
\text { fluorescens }\end{array}$ & 31 & 32 & 31 & 22 & 23 & 23 & 18 & 19 & 19 \\
\hline $\begin{array}{l}\mathrm{T}_{3}-75 \% \mathrm{RDF}+P . \\
\text { fluorescens }\end{array}$ & 33 & 34 & 33 & 23 & 24 & 24 & 19 & 20 & 20 \\
\hline $\begin{array}{l}\mathrm{T}_{4}-100 \% \mathrm{RDF}+P . \\
\text { fluorescens }\end{array}$ & 34 & 36 & 35 & 25 & 26 & 25 & 21 & 21 & 21 \\
\hline $\mathrm{T}_{5}-50 \% \mathrm{RDF}+\mathrm{HA}$ & 31 & 32 & 31 & 22 & 23 & 22 & 18 & 19 & 19 \\
\hline $\mathrm{T}_{6}-75 \% \mathrm{RDF}+\mathrm{HA}$ & 34 & 35 & 35 & 25 & 26 & 25 & 20 & 21 & 21 \\
\hline $\mathrm{T}_{7}-100 \% \mathrm{RDF}+\mathrm{HA}$ & 35 & 36 & 36 & 25 & 26 & 26 & 21 & 22 & 21 \\
\hline $\begin{array}{l}\mathrm{T}_{8}-50 \% \mathrm{RDF}+P . \\
\text { fluorescens }+\mathrm{HA}\end{array}$ & 34 & 35 & 34 & 24 & 25 & 25 & 20 & 21 & 20 \\
\hline $\begin{array}{l}\mathrm{T}_{9}-75 \% \mathrm{RDF}+P . \\
\text { fluorescens }+\mathrm{HA}\end{array}$ & 36 & 37 & 37 & 26 & 27 & 27 & 22 & 22 & 22 \\
\hline $\begin{array}{l}\mathrm{T}_{10}-100 \% \\
\mathrm{RDF}+\text { P.fluorescens }+\mathrm{HA}\end{array}$ & 40 & 41 & 40 & 29 & 30 & 29 & 24 & 25 & 25 \\
\hline SEm \pm & 1.20 & 1.24 & 1.21 & 0.91 & 0.95 & 0.93 & 0.76 & 0.89 & 0.78 \\
\hline $\mathrm{CD}(\mathrm{P}=0.05)$ & 3.57 & 3.68 & 3.59 & 2.71 & 2.82 & 2.75 & 2.25 & 2.63 & 2.31 \\
\hline
\end{tabular}

Table.3 Effect of $P$. fluorescens, humic acid and level of mineral fertilizers on enzymetic activity of cabbage rhizosphere soil at harvest

\begin{tabular}{|c|c|c|c|c|c|c|c|c|c|}
\hline \multirow[t]{2}{*}{ Treatments } & \multicolumn{3}{|c|}{$\begin{array}{l}\text { Dehydrogenase activity } \\
\left(\mu \mathrm{g} \text { TPF } \mathrm{g}^{-1} \text { soil } 24 \mathrm{~h}^{-1}\right)\end{array}$} & \multicolumn{3}{|c|}{$\begin{array}{l}\text { Urease activity } \\
\left(\mu \mathrm{g} \mathrm{UH} \mathrm{g}^{-1} \text { soil }^{-1}\right)\end{array}$} & \multicolumn{3}{|c|}{$\begin{array}{c}\text { Alkaline Phosphatase } \\
\text { activity }^{-1} \\
\left(\mu \mathrm{g} \text { PNP g } \text { soil h}^{-1}\right)\end{array}$} \\
\hline & 2009 & 2010 & Pooled & 2009 & 2010 & Pooled & 2009 & 2010 & Pooled \\
\hline $\mathrm{T}_{1}-100 \% \mathrm{RDF}$ & 92 & 90 & 91 & 227 & 223 & 225 & 35.0 & 35.7 & 35.4 \\
\hline $\begin{array}{l}\mathrm{T}_{2}-50 \% \mathrm{RDF}+P \text {. } \\
\text { fluorescens }\end{array}$ & 93 & 105 & 99 & 229 & 233 & 231 & 37.6 & 43.0 & 40.3 \\
\hline $\begin{array}{l}\mathrm{T}_{3}-75 \% \mathrm{RDF}+P . \\
\text { fluorescens }\end{array}$ & 111 & 118 & 115 & 259 & 262 & 261 & 45.0 & 49.5 & 47.2 \\
\hline $\begin{array}{l}\mathrm{T}_{4}-100 \% \mathrm{RDF}+P . \\
\text { fluorescens }\end{array}$ & 132 & 138 & 135 & 292 & 295 & 294 & 54.6 & 56.0 & 55.3 \\
\hline $\mathrm{T}_{5}-50 \% \mathrm{RDF}+\mathrm{HA}$ & 95 & 102 & 98 & 236 & 240 & 238 & 36.2 & 43.0 & 39.6 \\
\hline $\mathrm{T}_{6}-75 \% \mathrm{RDF}+\mathrm{HA}$ & 112 & 119 & 116 & 263 & 266 & 264 & 43.4 & 49.0 & 46.2 \\
\hline $\mathrm{T}_{7}-100 \% \mathrm{RDF}+\mathrm{HA}$ & 133 & 141 & 137 & 305 & 311 & 308 & 52.7 & 54.5 & 53.6 \\
\hline $\begin{array}{l}\mathrm{T}_{8}-50 \% \mathrm{RDF}+P . \\
\text { fluorescens }+\mathrm{HA}\end{array}$ & 97 & 105 & 101 & 243 & 256 & 249 & 39.2 & 43.6 & 41.4 \\
\hline $\begin{array}{l}\mathrm{T}_{9^{-}} 75 \% \mathrm{RDF}+P . \\
\text { fluorescens }+\mathrm{HA}\end{array}$ & 122 & 131 & 126 & 278 & 283 & 280 & 51.4 & 55.0 & 53.2 \\
\hline $\begin{array}{l}\mathrm{T}_{10}-100 \% \mathrm{RDF}+ \\
\text { P.fluorescens }+\mathrm{HA}\end{array}$ & 138 & 146 & 142 & 308 & 312 & 310 & 62.7 & 64.8 & 63.7 \\
\hline SEm \pm & 1.24 & 3.86 & 1.85 & 1.63 & 7.41 & 3.92 & 1.43 & 2.45 & 1.31 \\
\hline $\mathrm{CD}(\mathrm{P}=0.05)$ & 3.68 & 11.45 & 5.49 & 4.83 & 22.01 & 11.63 & 4.25 & 7.28 & 3.88 \\
\hline
\end{tabular}


The higher phosphatase activity in soil may be due to higher nitrogen content of the substrate, which in turn resulted in higher microbial activity. The increase in phosphatase activity following the addition of bio-organics could be due to the proliferation of phosphatase-producing microbes (Perucci et al., 1988). The phosphatase activity is directly related to content of organic carbon. The importance of organic carbon in nutrient cycling was evident from the fact that the enzyme activity quantified in the present study showed positive correlation with organic carbon.

This indicates that organic material significantly increases the enzymatic activity in soil. This finding is in accordance to Dick and Tabatabai (1984) they reported that the enzymes in the organics amended soils may also directly contribute to enzyme activities. Enzymatic activities of soils are usually correlated with their organic carbon and available nutrient contents (Taylor et al., 2002). Similar results were observed by Naseby and Lynch, 1998 and Ghaderi et al., (2008).

In conclusion, application of $100 \%$ RDF in combination with Pseudomonas fluorescens and humic acid appeared to be better microbial functional diversity in soil as microbial population and enzymatic activity. This treatment increased the nutrient uptake microbial population in rhizospheric soil and activities of urease, phosphatase and dehydrogenase in post harvest soil.

\section{Acknowledgements}

The authors wish to acknowledge Farm Incharge of horticulture farm, Department of Horticulture for providing facilities to conduct this research trial and authors are also thankful to the Head, Department of Soil Science and Agricultural Chemistry, Institute of Agricultural Sciences, BHU Varanasi, providing necessary facilities to conduct this research work.

\section{References}

Allison, F.E., Soulides, D.A. and Smith, J.H. 1962. Phosphobacteria as a soil inoculant. Tech US Dept Agricult. Bul., 1: 63-70.

Awasthi, R., R. Tewari and Harsh Nayyar. 2011. Synergy between Plants and PSolubilizing Microbes in soils: Effects on Growth and Physiology of Crops. Int. Res. J. Microbio. 2(12): 484-503.

Byrnes, B.H. and Amberger, A. 1989. Fate of broadcast urea in a flooded soil when treated with $\mathrm{N}$-(n-butyl. thiophospheric triamide, a urease inhibitor. Fertil. Resh., 18; 221-231.

Chefetz, B., Tarchitzky, J., Deshmukh, A.P., Hatcher, P.G. and Chen, Y. 2000. Structural characterization of soil organic matter and humic acids in particlesize fractions of an agricultural soil. Soil Sci. Am. J., 66: 129-141.

Dilly, O., Blume, H.P. and Munch, J.C. 2003. Soil microbila activites in luvisols and Anthrosols during 9 years of regiontypical tillage and fertilizer practices in northern Germany, Biogeochem., 65: 319-339.

Dinesh, R.S., Sharma, G.D. and Mishra R.R. 2000. Fertilizer application for specific yield targets of Sonora 64 (wheat). Indian Fmg. 17, 43-45.

Ding, G., Novak, J.M., Amarasiriwardena, D., Hunt, P.G. and Xing, B. 2002. Soil organic matter characteristics as affected by tillage management. Soil Sci. Soc. Am. J., 66: 421-429.

Douglas, L.A. and Bremner J.M. 1971. A rapid method of evalutiny different compound as inhibitors of urease in soils. Soil Biol. \& Biochm., 3: 309-315.

Doyle, J.D. and Stotzky. G. 1993. Methods 
for the detection of changes in the microbial ecology of soil caused by the introduction of micro-organisms. Microb. Release, 2: 63-72.

Doyle, J.D. and Stotzky. G. 1993. Methods for the detection of changes in the microbial ecology of soil caused by the introduction of micro-organisms. Microb Release, 2: 63-72.

Eissa, F.M., Faith, M.A. and El-Shall, S.A. 2007. The Role of humic acid and rootstock in enhancing salt tolerance of "Le-Conte" pear seedlings. J. Agric. Sci. Mansoura Univ., 32(5): 3651-3666.

Fliessbach, A., Winkler, M., Lutz, M.P., Oberholzer, H.R. and Mader, P. 2009. Soil amendment with Pseudomonas fluorescens CHA0: lasting effects on soil biological properties in soils low in microbial biomass and activity. Microbial Ecol., 57 (4): 611-623.

Ghaderi, F.A., Klein, T.M. and Koths, J.S. 2008. Urease, protease, and phosphatase in soil continuously cropped of corn. Soil Biol. Biochem., 12: 293-294.

Hassink, J. 1991. Effects of soil texture on the size of the microbial biomass and on the amount of $\mathrm{C}$ mineralized per unit of microbial biomass in Dutch grassland soils. Soil Biol. Biochem., 26: 15731581 .

Ismail, A.F., Hussien, S.M., El-Shall, S.A. and Fathi, M.A. 2007. Effect of irrigation and humic acid on Le-Conte pear. J. Agric. Sci. Mansoura Univ., 32(9): 7589-7603.

Jackson, M.L. 1973. Soil Chemical Analysis, Prentice Hall, Pvt. Ltd. New Delhi, pp. 239-241.

John-susan, K. and Abraham, A. 1995. Microbial Immobilization and mineralization of nutrients during different seasons of the year. J. Indian Soc. Soil Sci., 43: 47-52.

Kumari, L.M. 1961. Rhizosphere microflora and host parasite relationship. Ph.D.
Thesis, Universty Madras.

Manna, M.C., Kundu, S., Sing, M. and Takkar, P.N. 1996. Influence of FYM on dynamics of microbial biomass and its turnover and activity of enzymes under a soyabean-wheat system on a typic Haplustert. J. Indian Soc. Soil Sci., 44: 409-412.

Meena, V.S., Maurya, B.R., Verma, R., Meena, R.S., Jatav, G.K., Meena, S.K., Meena, R. and Meena, S.K. 2014. Soil microbial population and selected enzyme activities as influenced by concentrate manure and inorganic fertilizer in alluvium soil of Varanasi. The Biosacn, 8(3): 931-935,

Nannipieri, P., Pinton, R. and Varanini Z. 2002. The rhizosphere, pp. 141-158. New York, USA: Marcel Dekker.

Naseby, D.C. and Lynch, J.M. 1998. Soil enzymes and microbial population structure to determine the impact of wild type and genetically modified Pseudomonas fluorescens in the rhizosphere of pea. Mol. Ecol. 7, 617625.

Olsen, S.R. 1954. Estimation of available phosphorus in soils by extraction with sodium bicarbonate. USDA circular No. 939, Washingaton D C.

Panse, V.G. and Sukhatme, P.V. 1985. Statistical Methods for Agricultural Workers. Indian Council of Agricultural Research, New Delhi.

Patil, B. and Varade, P.A. 1998. Microbial Population in rhizosphere $\mathrm{s}$ influenced by high input rates of fertilizer application to sorghum on a vertiso. $J$. Indian Soc. Soil Sci., 46: 223-227.

Perucci, P., Sireno, I. and Bianchin, M.L. (1988. Enzyme activity and microbial biomass in a field soil amended with municipal refuse. Biol. Fertility of Soils, $14 ; 54-60$.

Rolf, A.O. and Bakken, L. R. 1987. Vibility of soil bacteria: optimization of plate 
counting technique and comparison between total counts and plate counts within different size groups. Microbial Ecol., 13: 59-74.

Selamuthu, K.M. and Govindaswamy, M. 2003. Effect of fertilizer and humic acid on rhizosphere micro-organisms and soil enzymes at an early stage of sugarcane growth. Sugar. Tech., 5(4), 273-277.

Subbiah, B.V. and Asija, G.L. 1956. A rapid procedure for estimation of available $\mathrm{N}$ in soils. Curr. Sci., 25; 259-260.

Tabatabai, M.A. 1994. Soil enzymes In: Weaver RW, Angle JS and Bottomley PS (Eds. Methods of soil analysis, part 2. Microbiological and biochemical properties. SSSA Book Series No. 5. Soil Sci. Soc. Am. Madison, Wis., pp. 775-833.

Tabatabai, M.A. and Bremner, J.M. 1986. Use of pnitrophenylphosphate for assay of soil phosphatase activity. Soil Biol. Biochem., 1: 301-307

Tarafdar, J.C. and Jungk, A. 1987. Phosphatase activity in the rhizosphere and its relation to the depletion of soil organic phosphorus. Biol. Fertility of Soils, 3: 199-204.

Taylor, W.J., Rangkadilok, N., Nicolas, M.E. Bennett, R.N., Eagling, D.R. and
Premier, R.R. 2002. The effect of sulfur fertilizer on glucoraphanin levels in broccoli (B. oleracea L. var. italica. at different growth stages. J. Agric. Food Chem., 52: 2632-2639.

Timothy K.H. and Thomas G.B. 2010. Humic Substances Generally Ineffective in Improving Vegetable Crop Nutrient Uptake or Productivity. Hort. Sci., 45(6): 906-910.

Verma, R., B.R. Maurya and Vijay Singh Meena. 2014. Integrated effect of bioorganics with chemical fertilizer on growth, yield and quality of cabbage (Brassica oleracea var capitata). Indian J. Agri. Sci., 84(8): 914-9.

Walkely, A. and Black, C.A. 1934. Estimation of organic carbon by chromic acid titration method. Soil Sci., 37: 28-29.

Wlodarczyk, T., Stepniewski W. and Brzezinska, M. 2002. Dehydrogenase activity, redox potential, and emissions of carbon dioxide and nitrous oxide from Cambisols under flooding condition. Biol. Fertility of Soils, 36: 200-206.

Yassen, A.A. and Khalid, K.A. 2009. Influence of organic fertilizers on the yield, essential oil and mineral content of onion. Int. Agrophysics, 23: 183-188.

\section{How to cite this article:}

Verma, R., B.R. Maurya, V.S. Meena, M.L. Dotaniya, and Deewan, P. 2017. Microbial Dynamics as Influenced by Bio-organics and Mineral Fertilizer in Alluvium Soil of Varanasi, India. Int.J.Curr.Microbiol.App.Sci. 6(2): 1516-1524.

doi: http://dx.doi.org/10.20546/ijcmas.2017.602.169 